Journal of Advanced Research in Fluid Mechanics and Thermal Sciences

Journal homepage: www.akademiabaru.com/arfmts.html ISSN: 2289-7879

\title{
Simulation the Effects of Solar Radiation in the Cavity Receiver by Using ANSYS for the Application in The Solar Power Generator
}

\author{
Yusra M. Abdullah ${ }^{1, *}$ \\ 1 College of Science, Physics Department, Mosul University, Iraq
}

\section{ARTICLE INFO \\ ABSTRACT}

\section{Article history:}

Received 25 February 2020

Received in revised form 31 March 2020

Accepted 3 April 2020

Available online 24 April 2020

\begin{abstract}
This paper aims to investigate the effects the solar radiation on the cavity receiver for the Application in the Solar Power Generator (SPG). In order to perform work the solar power generator, high concentrated solar radiations are needed. thus, investigation of heat transfer of the cavity receiver is needed to conduct max usage of solar energy with min losing of heat for performance for the Solar Power Generator (SPG), in this research, Ansys software has been conducted to perform simulation process by using experimental results as a primary data for validation purpose. The experiments were conducted to find out the suitable aperture ration $(A R=d / D)$ and aperture position (AP $=H / D)$ of the cavity receiver $(A R=0.5 \mathrm{AP}=0.53)$. The results that done by simulation were confident $91 \%$ with the experiments results. The simulation process is conducted for solar radiation along the wall surface $(\mathrm{H})$ of the receiver for different boundary conditions of the cavity receiver.
\end{abstract}

Keywords:

power generator; solar energy; radiation; cavity receiver; simulation

\section{Introduction}

Power and climate in today's world is an important issue. CO2 emissions are the main reason behind the global warming. New environmentally friendly and efficient power systems have become very relevant and need to be built as a matter of urgency [1]. To accomplish this mission, Solar Power Generation is a useful approach. Since the sun is the most efficient source, high insolation regions (more than $500 \mathrm{~W} / \mathrm{m} 2$ ) therefore have an advantageous choice to build environmentally friendly solar power plants" [2-3]. Particularly in Mediterranean countries, like South Europe, Middle East and North Africa (MENA Region), solar power is highly suitable for large-scale industrial exploitation" [4]. (SAPG) is a hybrid power system incorporated in a regenerative Rankine cycle power plant by solar thermal energy. In such a hybrid power system, the solar thermal energy provided by the heat transfer fluid (HTF) preheats the feed water of the Rankine cycle power plant. Thus, the HTF displaces

\footnotetext{
* Corresponding author.

E-mail address: yussra_aphy@yahoo.com (Yusra M. Abdullah)
}

https://doi.org/10.37934/arfmts.70.1.8996 
the power plant's extraction vapor used to preheat the feed water. The arrangement of the SP is referred to as the specification of the SP. Four different SP configurations are suggested by Li et al., [5]. In a SAPG power plant, the extraction steam should be modified within response to the changes in the HTF flow rate input into the SP, which is called the SP operating strategy. Three standard SP organizational approaches are in place [1]. Each SP configuration can be implemented in one of the three SP operating strategies in a SAPG factory. The SP configuration and SP operating plan combinations are referred to as "configuration-operation combinations. Most of the previous SAPG studies were based on a single combination of configuration-operation. The initial studies on SAPG were focused on the SP configuration which SP is performed in accordance with the FWH of the power station [6-7]. Some other studies are based on the configuration of the SP in series with the FWH of the power plant [7-8]. The SP technique for these studies is based on the assumption that the extraction steam is balanced to preserve the FWH feed water outlet temperature constant. Recently proposed the development of 12 possible "configuration-operation combinations for a SAPG plant [9-10]. The instantaneous and annual technological output of the 12 combinations proposed was compared. It has been found that a SAPG plant with different combinations would have different instantaneous solar to energy efficiency and annual network solar to energy efficiency with the same solar thermal input and solar collector area [11-12]. The effect on the annual net solar output of the different annual solar radiation has not, however, been evaluated. The annual net energy efficiency of the solar system was determined by annual solar radiation [13-14]. The present study discusses the solar energy generation systems with a Fresnel lens that directs light to the heating chamber receiver. The chamber's opening is called aperture. The aspect of transparency and its positions is very critical. Through increasing the opening to a minimum, the convective heat loss can be minimized. Because there is a relationship between solar radiation and heat loss from the opening, statistical and experimental research has taken place to minimize and to find an exact mechanism of convective heat loss.

\section{Methodology}

\subsection{Primary Boundary Condition}

The experiments configuration has been set as primary boundary conditions of this study. In the current study, the constant state behavior of the air film temperature profiles is the height of the cavity. The contrast between $\mathrm{H}=85 \mathrm{~mm}$ and $\mathrm{H}=165 \mathrm{~mm}$ showed that at aperture a temperature at $545 \mathrm{~K}$ at $\mathrm{H}=85 \mathrm{~mm}$ was also high compared to the $165 \mathrm{~mm}(420 \mathrm{~K}$ ) cavity receiver. since cavity receiver is uniform shape and steady state, that's lead to reveal the value of energy at each point along high of the cavity by using linear interpolation theory [1] as shown in the Table 1.

Table 1

Results of experimental data

\begin{tabular}{ll}
\hline High $(\mathrm{mm})$ & Temperature $(\mathrm{K})$ \\
\hline 85 & 545 \\
100 & 521.5 \\
130 & 474.6 \\
165 & 420 \\
\hline
\end{tabular}

\subsection{Meshing and Geometry}


The case of this study can be understood by commercial software. ANSYS technology was selected to conduct this study simulation process. This program is well known for the development and simulation of radiation and thermal transfer aspects to solve the equations and to generate the appropriate solutions. which builds and applies the mesh on the geometrical depiction of the problem under investigation [15-16]. Both processing and post-processing phases are performed by the specific tool of ANSYS. Table 2 is showing the details of the geometry of cavity receiver [17].

Table 2

Geometry details of cavity receiver

\begin{tabular}{ll}
\hline Item & Dimension $(\mathrm{mm})$ \\
\hline Inner diameter & 155.6 \\
Outer diameter & 311.3 \\
\hline
\end{tabular}

The meshed design uses Tri type pave elements in complex areas and Quad type paves in the rest areas are shown in Figure 1. ANSYS provides full mesh versatility with amorphous meshes and can be polished or roughened according to the solution. After the grid was read into ANSYS.

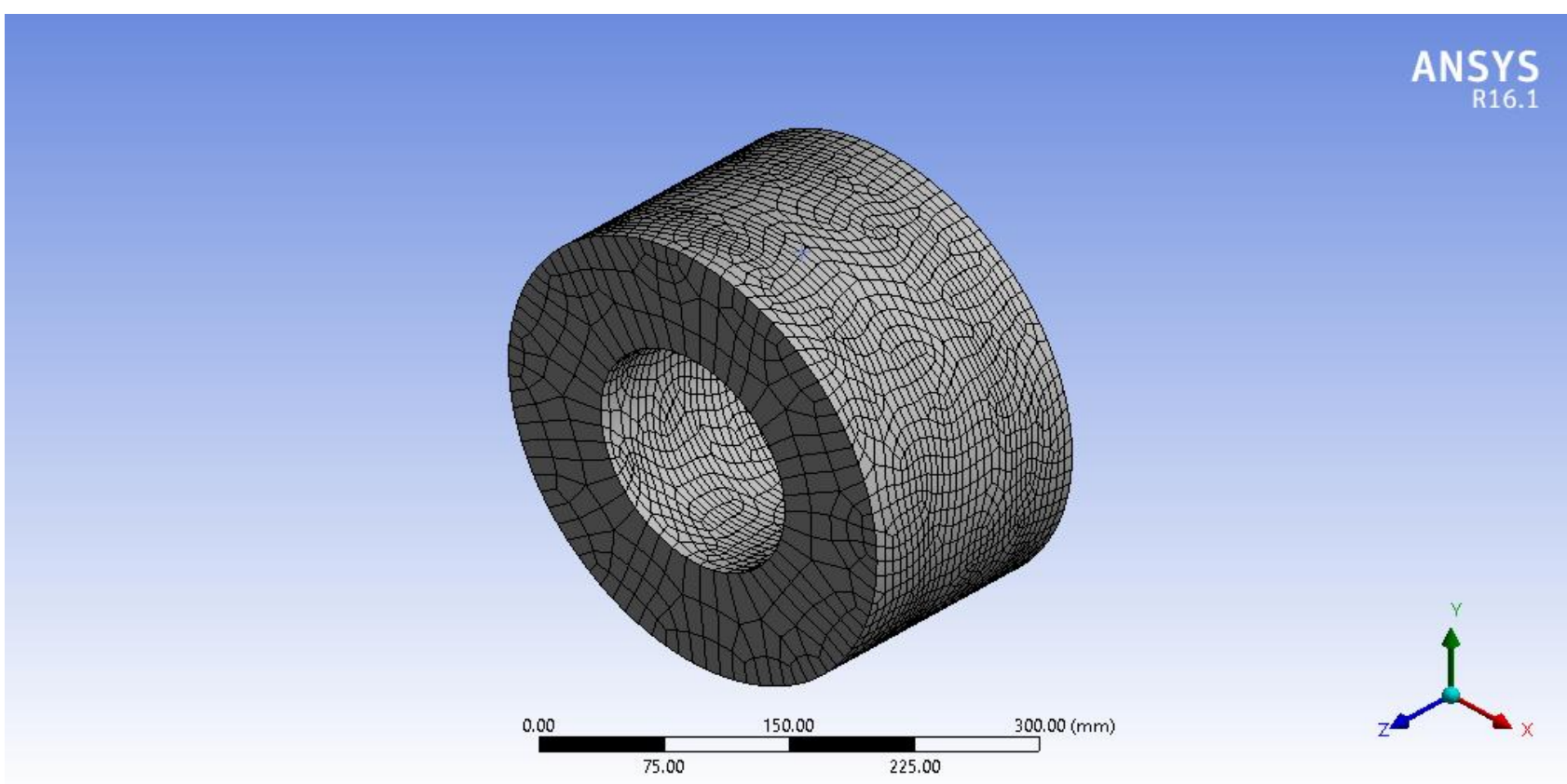

Fig. 1. Meshed model

\section{Results and Discussion}

The results of the current study have been presented and discussed with reference to the aim of the study, which was to determine the influence of radiation and its relationship with heat loss by using numerical method. Experimental data were employed to validate simulation results.

\subsection{FEA Procedure}

The FEA model is made by ANSYS. The modal analysis is carried out in order to compare the model with the heat loss and the mode shapes obtained from the simulation with the experimental results. The findings are checked after the transition method and modal review. Figure 2 demonstrates all 
simulator research process. For a specified input boundary conditions, output heat loss can be derived from the simulation.

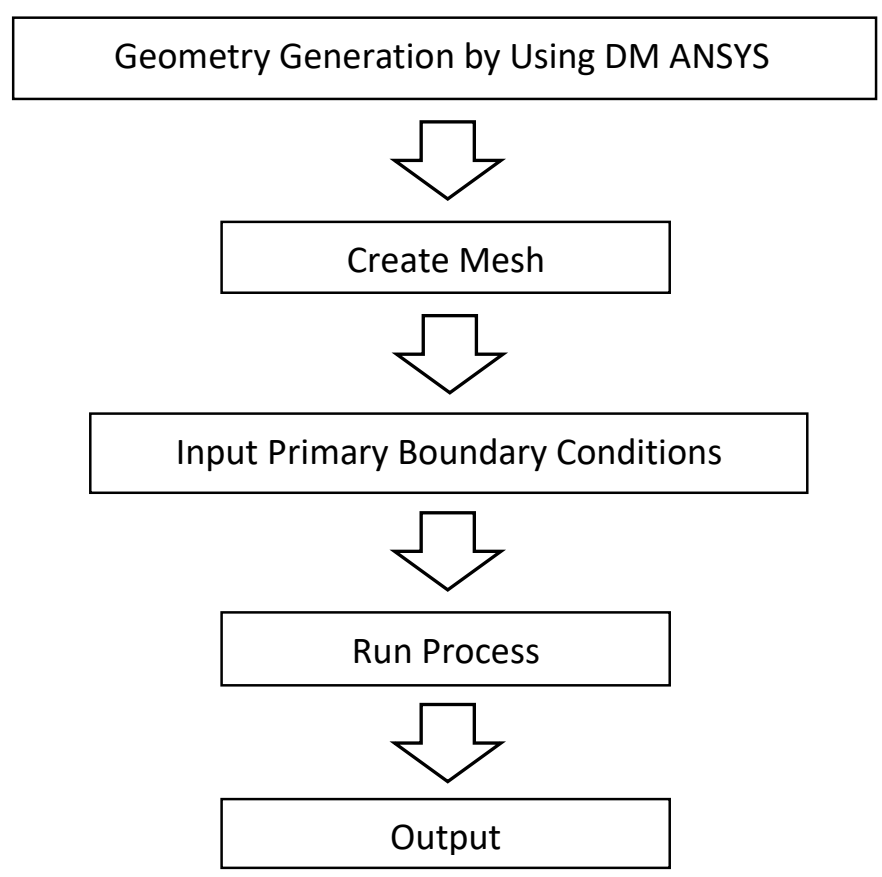

Fig. 2. Operation process

\subsection{Code Validation (Heat Pipe with Cavity Receiver (Type-IV, AR=0.5 AP =0.53))}

In order to carry out the validation process of the current study, Type-IV configuration of cavity receiver has been conducted for verification process. Figure 3 shows the simulation of origin experimental. With a cavity receiver design of type IV, the height of the cavity receiver was only 85 $\mathrm{mm}$, so lower cavity receiver height would possibly be heated directly. However, this cavity receptor height should be ideal as high wind speeds can contribute to large convective heat losses with low AP.

In the case of a tracking error or difference in the absorbed radiation, a cavity receiver should be able to store enough energy within the spectrum accessible in order to prevent rapid temperature drops from HP ground or water.
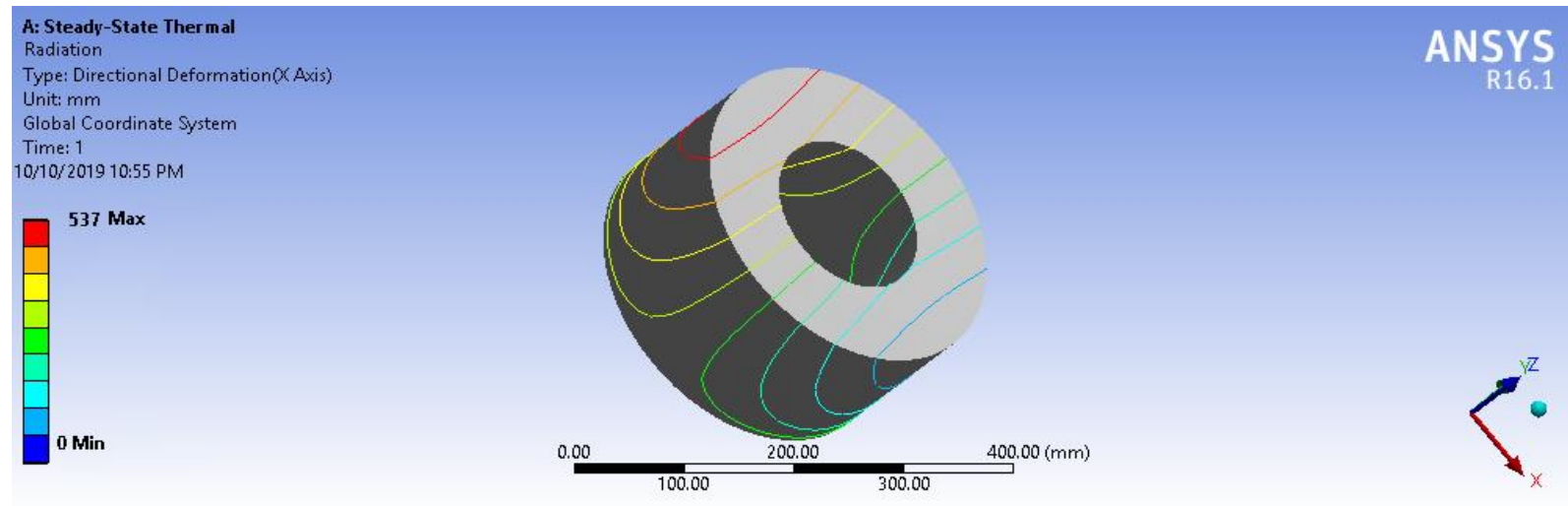

Fig. 3. Simulation of origin experimental 
The simulation results compared to the experimental results are listed in Table 3. Comparing two different heights $\mathrm{H}=85 \mathrm{~mm}$ and $\mathrm{H}=165 \mathrm{~mm}$, the temperature of the opening at $545 \mathrm{~K}$ at $\mathrm{H}=85 \mathrm{~mm}$ was similar to that of the cavity receptor $165 \mathrm{~mm}$ (420 K). Figure 4 shows the simulation results compared to the experimental results.

Table 3

Simulation results compared to the experimental results

\begin{tabular}{lll}
\hline High $(\mathrm{mm})$ & Experimental results $(\mathrm{K})$ & Simulation results $(\mathrm{K})$ \\
\hline 85 & 545 & 537 \\
100 & 521.5 & 523 \\
130 & 474.6 & 485 \\
165 & 420 & 430 \\
\hline
\end{tabular}

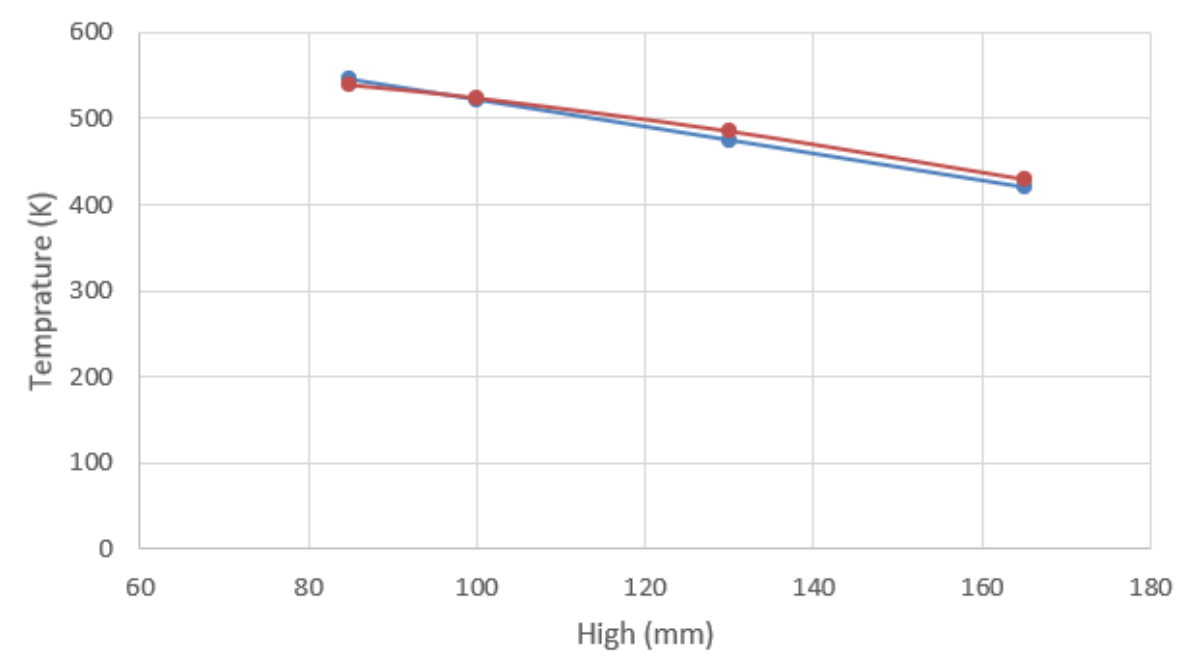

Fig. 4. Simulation results compared to the experimental results

\subsection{Heat Pipe with Modified Cavity Receiver $(A R=0.6 A P=0.66)$}

In this trial the $A R=0.6, A P=0.66$ will be conducted to generate a new design. Table 4 is showing the dimensions of the cavity receiver that used in solar power generation. Inner and outer diameter is calculated by depending on these $A R=0.6, A P=0.66$ ratios. The geometry of the new trial has generated and meshed by using Design Modular (DM) in the ANSYS software.

\section{Table 4}

Geometry details of modified cavity receiver

\begin{tabular}{ll}
\hline Item & High $(\mathrm{mm})$ \\
\hline Inner diameter & 181.5 \\
Outer diameter & 275 \\
\hline
\end{tabular}

Table 5 is shown the results of simulation process that have carried out by using ANSYS on the long side high of the cavity receiver of solar power generator where the maximum value of the heat radiation at the top of the cavity tube. 
Table 5

Simulation results of modified cavity receiver

\begin{tabular}{ll}
\hline High & Simulation results $(K)$ \\
\hline 85 & 510 \\
100 & 490 \\
130 & 440 \\
165 & 380 \\
\hline
\end{tabular}

The graph in the Figure 5 is representing that the relationship between the radiation at the different points of the high of the cavity receiver. The results of the simulation have proven that the total radiation on the alongside of the cavity receiver is changeable due high the geometry. The maximum heat exchange is happened at the bottom at the bottom of the cavity recover that's mean max heat radiation is happened the top of cavity receiver. Four main, main have considered to study the whole philosophy behaviour of cavity receiver towards of the heat radiation and heat loss as well.

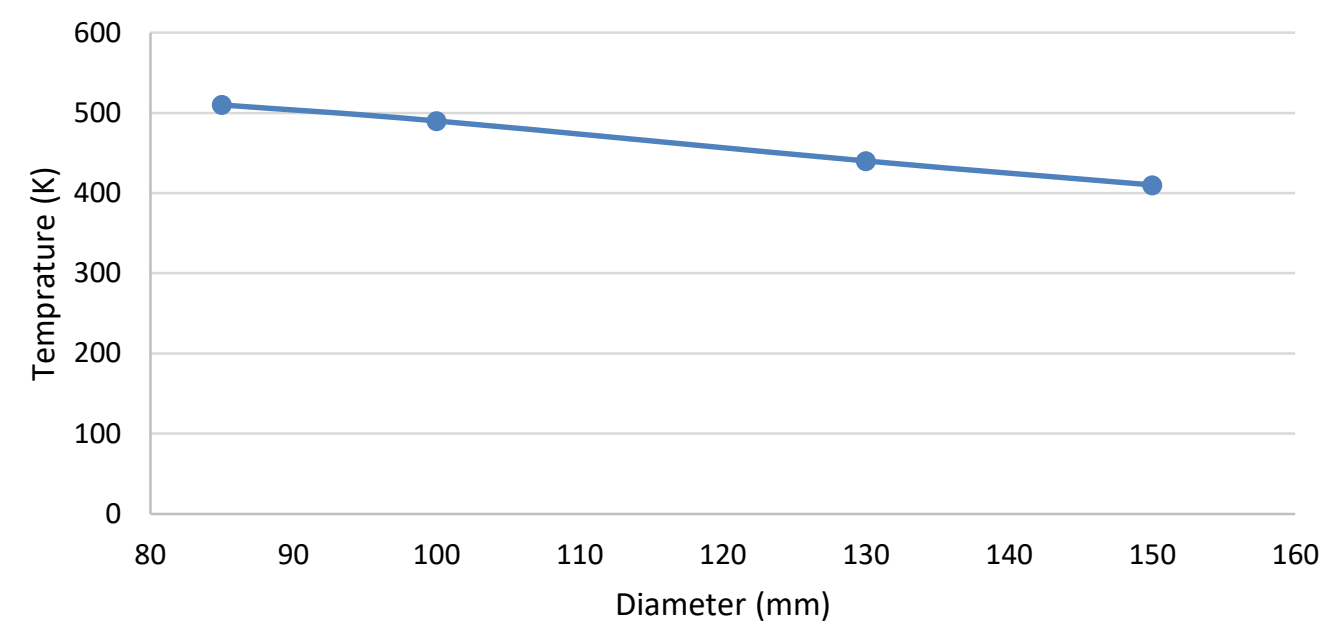

Fig. 5. Heat loss and at each pints of modified cavity receiver

ANSYS software has been conducted to carry out the simulation process of the cavity receiver of Solar Power Generator (SPG) by using the Steady-State Thermal tool. Heat radiation is employed to be discussed and studied in this study. Figure 6 is shown the heat transfer along of high of the geometry.

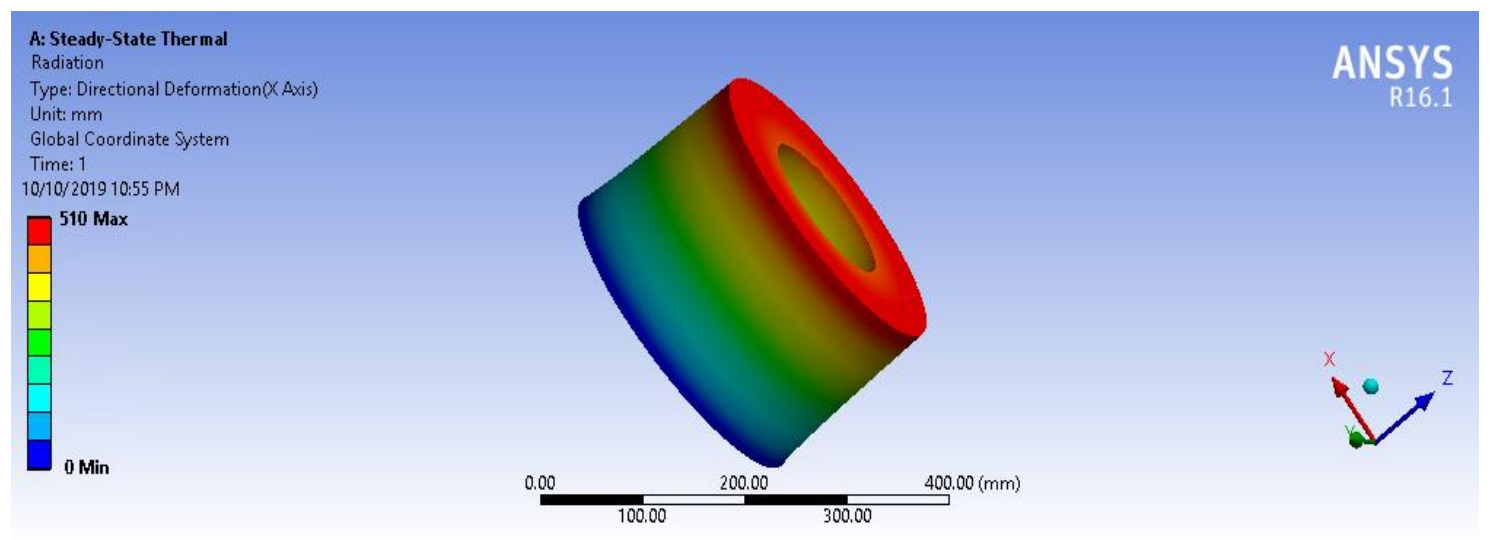

\section{Conclusion}

Fig. 6. Simulation process of modified cavity receiver 
Simulation process has been conducted to investigated in this study. Heat loss was employed used to predict the heat radiation in cavity receiver of Solar Power Generator (SPG). Ansys software has been conducted to carry out simulation process by depending on the Steady-State Thermal tool. A model was created and meshed by using Design Modular in ANSYS software. Model was validated with the experiment results. simulation results were confident by 2 percent error. The results have shown that heat loss decease with increasing of high of the cavity receiver that's meant heat radiation was happened the top of the cavity receiver.

\section{References}

[1] Boyle, Godfrey. Renewable energy. No. Sirsi) i9780199261789. Open University., 2004.

[2] Hosenuzzaman, Md, Nasrudin Abd Rahim, J. Selvaraj, Mohammad Hasanuzzaman, ABM Abdul Malek, and Afroza Nahar. "Global prospects, progress, policies, and environmental impact of solar photovoltaic power generation." Renewable and Sustainable Energy Reviews 41 (2015): 284-297.

https://doi.org/10.1016/i.rser.2014.08.046

[3] Aman, M. M., K. H. Solangi, M. S. Hossain, A. Badarudin, G. B. Jasmon, Hazlie Mokhlis, A. H. A. Bakar, and Salim Newaz Kazi. "A review of Safety, Health and Environmental (SHE) issues of solar energy system." Renewable and Sustainable Energy Reviews 41 (2015): 1190-1204.

https://doi.org/10.1016/i.rser.2014.08.086

[4] Wiser, Ryan, Dev Millstein, Trieu Mai, Jordan Macknick, Alberta Carpenter, Stuart Cohen, Wesley Cole, Bethany Frew, and Garvin Heath. "The environmental and public health benefits of achieving high penetrations of solar energy in the United States." Energy 113 (2016): 472-486.

https://doi.org/10.1016/j.energy.2016.07.068

[5] Li, Hongqiang, Xiaofeng Zhang, Lifang Liu, Rong Zeng, and Guoqiang Zhang. "Exergy and environmental assessments of a novel trigeneration system taking biomass and solar energy as co-feeds." Applied Thermal Engineering 104 (2016): 697-706.

https://doi.org/10.1016/j.applthermaleng.2016.05.081

[6] Zeaiter, Joseph, Fouad Azizi, Mohammad Lameh, Dia Milani, Hamza Y. Ismail, and Ali Abbas. "Waste tire pyrolysis using thermal solar energy: An integrated approach." Renewable energy 123 (2018): 44-51.

https://doi.org/10.1016/j.renene.2018.02.030

[7] Ramanathan, S. "Experimental Investigation of Latent heat thermal energy storage using Solar Absorption Refrigeration System." International Research Journal of Automotive Technology 1, no. 6 (2018): $186-192$.

[8] Mehrpooya, Mehdi, and Ali Dadak. "Investigation of a combined cycle power plant coupled with a parabolic trough solar field and high temperature energy storage system." Energy Conversion and Management 171 (2018): 16621674.

https://doi.org/10.1016/i.enconman.2018.07.001

[9] Tehrani, S. Saeed Mostafavi, Robert A. Taylor, Karthik Nithyanandam, and Ardalan Shafiei Ghazani. "Annual comparative performance and cost analysis of high temperature, sensible thermal energy storage systems integrated with a concentrated solar power plant." Solar Energy 153 (2017): 153-172. https://doi.org/10.1016/i.solener.2017.05.044

[10] Good, Clara, Inger Andresen, and Anne Grete Hestnes. "Solar energy for net zero energy buildings-A comparison between solar thermal, PV and photovoltaic-thermal (PV/T) systems." Solar Energy 122 (2015): 986-996.

https://doi.org/10.1016/i.solener.2015.10.013

[11] Stutz, Benoît, Nolwenn Le Pierrès, Frederic Kuznik, Kévyn Johannes, Elena Palomo Del Barrio, Jean-Pierre Bedecarrats, Stéphane Gibout et al. "Storage of thermal solar energy." Comptes Rendus Physique 18, no. 7-8 (2017): 401-414. https://doi.org/10.1016/j.crhy.2017.09.008

[12] Khelifa, A., K. Touafek, H. Ben Moussa, and I. Tabet. "Modeling and detailed study of hybrid photovoltaic thermal (PV/T) solar collector." Solar Energy 135 (2016): 169-176.

https://doi.org/10.1016/i.solener.2016.05.048

[13] kadhim Sharaf, Hussein, Nawal Aswan Abdul Jalil, and Sadeq Salman. "A simulation on the effect of ultrasonic vibration on ultrasonic assisted soldering of Cu/SAC305/Cu joint." Journal of Advanced Research in Applied Mechanics 36, no. 1 (2017): 1-9.

[14] Tian, Yuan, and Chang-Ying Zhao. "A review of solar collectors and thermal energy storage in solar thermal applications." Applied energy 104 (2013): 538-553. 
https://doi.org/10.1016/j.apenergy.2012.11.051

[15] Tritt, Terry M., Harald Böttner, and Lidong Chen. "Thermoelectrics: Direct solar thermal energy conversion." MRS bulletin 33, no. 4 (2008): 366-368.

https://doi.org/10.1557/mrs2008.73

[16] Abdullah, Amira Lateef, Suhaimi Misha, Noreffendy Tamaldin, and Mohd Afzanizam Mohd. "Numerical analysis of solar hybrid photovoltaic thermal air collector simulation by ANSYS." CFD Letters 11, no. 2 (2019): 1-11.

[17] Hashim, Ghasaq Adheed, and NA Che Sidik. "Numerical study of harvesting solar energy from small-scale asphalt solar collector." Journal of Advanced Research Design 2, no.1 (2014): 10-19. 